\title{
Alpha-2 Globulin to Total Protein Ratio Measurement
}

National Cancer Institute

\section{Source}

National Cancer Institute. Alpha-2 Globulin to Total Protein Ratio Measurement. NCI

Thesaurus. Code C92255.

The determination of the ratio of alpha-2 globulin compared to total protein present in a sample. The measurement may be expressed as a ratio or percentage. 